\title{
Flow dynamics of the Rutford Ice Stream ice-drainage basin, West Antarctica, from radar stratigraphy
}

\author{
E.C. KING \\ British Antarctic Survey, Natural Environment Research Council, Madingley Road, Cambridge CB3 OET, UK \\ E-mail: ecki@bas.ac.uk
}

\begin{abstract}
Rutford Ice Stream, West Antarctica, drains a catchment of $>45000 \mathbf{~ k m}^{2}$ into the Ronne Ice Shelf through a $26 \mathrm{~km}$ wide, $2.4 \mathrm{~km}$ deep subglacial trough adjacent to the Ellsworth Mountains. Fortytwo per cent of its catchment boundary is common with Pine Island Glacier, where rapid change to ice dynamics is currently underway. These changes may eventually affect adjacent catchments such as Rutford. Radar sounding data were acquired over the Rutford ice-drainage basin that show the internal structure. In particular, distinctive reflector groups were identified that mark the boundaries between four different flow elements. The flow-margin reflector groups include curvilinear events that cross-cut isochrones and are therefore likely to be post-depositional. These reflections may arise from crystal orientation fabrics generated by localized strain in a flow margin. One of the sectors of the ice-drainage basin supplies the largest share $\mathbf{( 3 8 \% )}$ of the ice volume flux through the main trunk of Rutford Ice Stream. This sector may be preferentially affected by continuing surface lowering in the Pine Island Glacier catchment.
\end{abstract}

\section{INTRODUCTION}

Rutford Ice Stream drains $2.6 \%$ of the grounded portion of the West Antarctic ice sheet into the Weddell Sea via the Ronne Ice Shelf. The ice stream shares a catchment boundary with Pine Island Glacier, an ice stream that drains into the Amundsen Sea and is currently undergoing rapid changes in flow regime: the flow speed is accelerating, the ice is thinning and therefore the surface is lowering (Rignot, 1998; Shepherd and others, 2001; Joughin and others, 2003). If these changes in Pine Island Glacier propagate upstream, then the ice divides with adjacent ice streams may eventually be affected, potentially causing other catchments to shrink as that of Pine Island Glacier grows. In order to monitor and predict future changes in the West Antarctic ice sheet around Pine Island Glacier, it is necessary to determine the present ice dynamics in the adjacent catchments.

Here I extend previous studies on the main trunk of Rutford Ice Stream (Frolich and others, 1989; Doake and others, 2001; Vaughan and others, 2008) to determine the flow dynamics of the upstream reaches of the Rutford catchment basin. I analyse satellite imagery, surface and basal topography and radio-echo sounding data to determine the internal structure of the basin through a zone of convergent flow. Characteristic patterns in the radar stratigraphy can be identified in a series of transverse radar profiles that define separate flow elements. The flux of ice through four gates, across one sector of the drainage basin, was calculated. The aim of this paper is to determine the internal structure of the drainage basin to constrain future forcebalance models for this basin.

\section{RUTFORD ICE STREAM ICE-DRAINAGE BASIN}

Rutford Ice Stream drains ice from a $45600 \mathrm{~km}^{2}$ catchment basin (Doake and others, 1987, 2001; Frolich and others, 1989; Joughin and Bamber, 2005) into the Ronne Ice Shelf (Fig. 1). The catchment includes parts of the Ellsworth Mountains and areas to the west, north and east of those mountains.
The catchment boundary was defined using the surface elevation and a moderate-resolution imaging spectroradiometer (MODIS) satellite image of the area (Fig. 1a and b) (T. Haran and others, http://nsidc.org/data/nsidc-0280.html). There are some small differences to previous definitions of the catchment boundary (Liu and others, 1999; Doake and others, 2001; Vaughan and others, 2001; Joughin and Bamber, 2005), particularly in the area between the Rutford basin and the southern lobe of the Pine Island Glacier basin (Fig. 1). In this area the ice divide is parallel to the direction down the steepest surface slope, and small differences between different digital elevation models used to calculate the flow direction can move the mapped location of the divide by several kilometres.

The basin can be divided into four sectors on the basis of the surface morphology (Fig. 1) and the surface flow velocities as determined by interferometric synthetic aperture radar (InSAR) (Joughin and others, 1999; Fig. 1d):

Sector A feeds ice into the western margin of the ice stream through valley glaciers in the mountain range and through two tributaries draining slopes immediately west of the mountains that flow through narrow, steep-sided basal troughs.

Sector B feeds ice to the central part of the ice stream from areas adjacent to the ice divide between the Rutford basin and the southern lobe of the Pine Island Glacier basin (Vaughan and others, 2001).

The upstream boundary of sector $\mathrm{C}$ is partly the divergent divide with the Pine Island Glacier catchment and partly a flow-parallel divide with the Evans Ice Stream basin.

Sector D comprises the western slopes of Kealey Ice Rise and Fletcher Promontory, which feed ice to the eastern margin of Rutford Ice Stream.

The flow from these four sectors converges into the main trunk of the ice stream where the flow speed is $350-400 \mathrm{~m} \mathrm{a}^{-1}$, the width averages about $26 \mathrm{~km}$ and the 

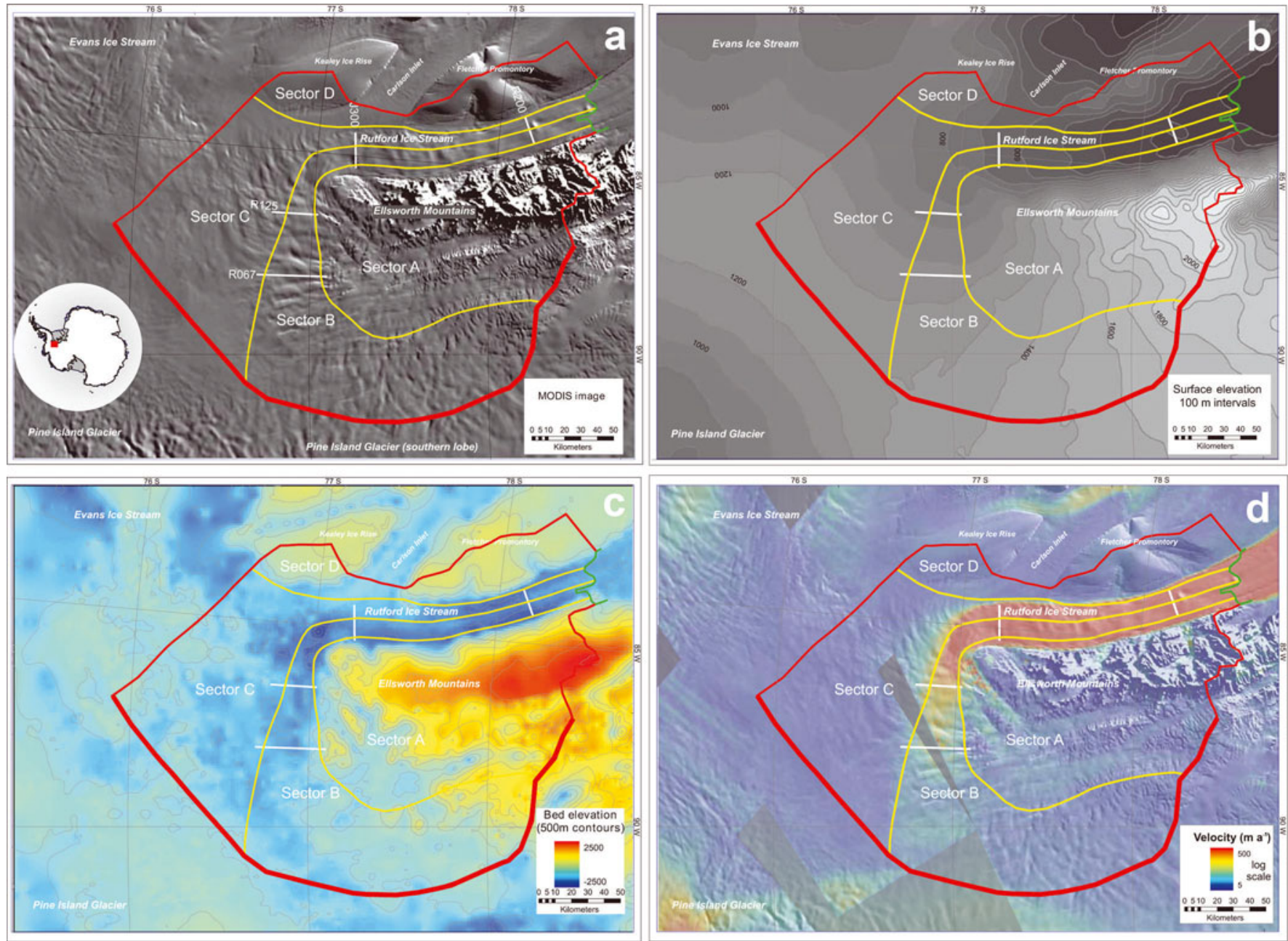

Fig. 1. Maps of the Rutford Ice Stream ice-drainage basin: (a) MODIS multispectral scanner image; (b) surface elevation; (c) bed elevation; and (d) surface velocity from InSAR (personal communication from I. Joughin, 2007). In each case, the red line marks the catchment boundary (bold where common with Pine Island Glacier), yellow lines mark sector boundaries, the green line is the grounding line and the white lines mark the locations of the radar profiles shown in Figure 2.

ice-volume flux is around $20 \mathrm{~km}^{3} \mathrm{a}^{-1}$ (Crabtree and Doake, 1982; Joughin and Bamber, 2005).

\section{RADAR DATA}

\section{Collection and processing}

All the radar data were collected using the British Antarctic Survey's Deep Look Radio Echo Sounder (DELORES). This is a monopulse radar operating in the $1-4 \mathrm{MHz}$ range that is based on designs developed by the University of Washington, WA, USA, (Gades, 1998) and St Olaf College, MN, USA (Welch and Jacobel, 2003). The transmitter uses a $\pm 2000 \mathrm{~V}$ pulser that has a variable firing rate between 1 and $5 \mathrm{kHz}$. The antennae are resistively loaded wire dipoles, and the receiver uses a chassis computer with a $100 \mathrm{MHz}$ digitizing card and is capable of stacking 3000 traces. The system is towed behind a snowmobile at $10-20 \mathrm{~km} \mathrm{~h}^{-1}$, so the distance between traces was $5-10 \mathrm{~m}$. I collected approximately $2500 \mathrm{~km}$ of radar profiles during two Antarctic field seasons. The data were processed using the ReflexW software in the following sequence: edit; background removal to suppress the effects of the direct (airwave) arrival; bandpass filter to increase the signal-to-noise ratio; amplitude correction to compensate for spherical spreading; and Kirchhoff migration to focus diffracted energy to its source point.

\section{Data description}

Four radar profiles are presented (Fig. 2), each positioned orthogonal to the flow direction, distributed along the length of the ice stream from $40 \mathrm{~km}$ upstream of the grounding line to $240 \mathrm{~km}$ upstream (Fig. 1). Average flow speed is $87 \mathrm{~m} \mathrm{a}^{-1}$ for the most upstream profile (R067), $129 \mathrm{ma}^{-1}$ (R125), $276 \mathrm{ma}^{-1}$ (J300) and $375 \mathrm{ma}^{-1}$ at the downstream profile (R200). The profiles will now be described from upstream to downstream.

\section{Profile R067 (Fig. 2a)}

This profile is $45 \mathrm{~km}$ long and oriented north-south. It was acquired in the 2005/06 field season using $40 \mathrm{~m}$ transmit and receive antennae that have a centre frequency near 1.2 $\mathrm{MHz}$. At the southern end of the line, the bed is at a depth of $1500 \mathrm{~m}$ over the most northerly part of the Ellsworth Mountains topographic high (Fig. 1d). Complex overlapping reflections over this high suggest a deeply dissected topography in three dimensions. The basal topography drops $500 \mathrm{~m}$ between 3.8 and $5 \mathrm{~km}$ along the profile, marking the edge of the Ellsworth high. The ice is about $2760 \mathrm{~m}$ thick 

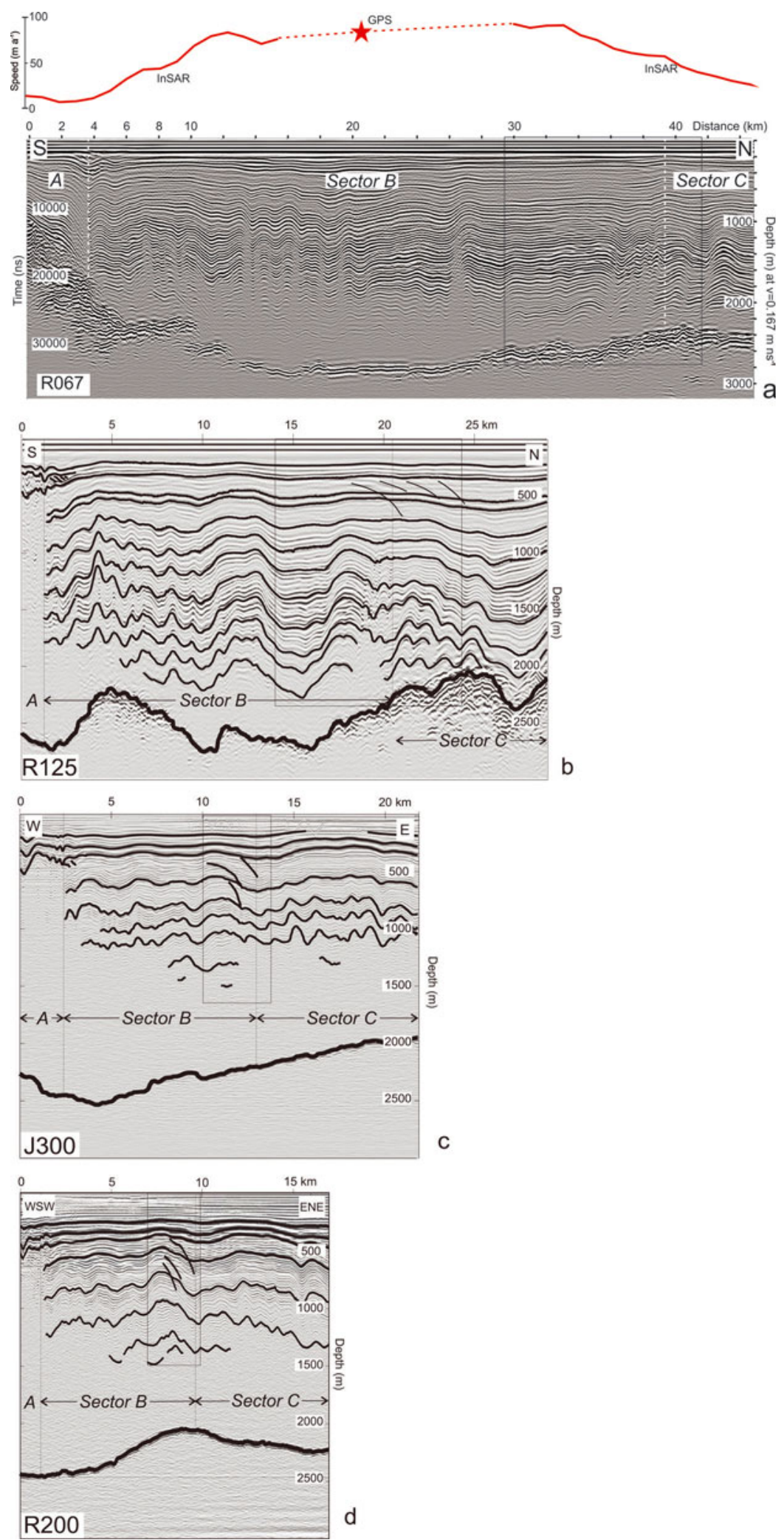

Fig. 2. Radar profiles. Boxes in (a-d) show location of detailed images in Figure 3a-d respectively. Ice flow is out of the page in each case. (a) Profile R067 (south-north). Data collected with a $1.2 \mathrm{MHz}$ monopulse radar and processed using a bandpass filter, spherical spreading correction and migration. The migration aperture for this display was kept narrow to suppress migration noise from shallow bedrock reflections at the south end of the profile. Flow-speed profile taken from InSAR data (solid line) and from ground-based global positioning system (GPS) measurement (red star). (b-d) Profiles R125 (south-north) (b), J300 (west-east) (c) and R200 (west-southwest-east-northeast) (d) with selected isochrones picked out for clarity.

between 13 and $27.5 \mathrm{~km}$ in the deepest part of an enclosed basin. The bed reflection in this section is relatively smooth compared to the rest of the profile. Seismic data suggest that soft, water-saturated sediment forms the bed in this area
(King and others, 2004). The adjacent areas of rougher basal topography are likely to be outcrops of stiff till similar to those identified elsewhere on the ice stream by seismic survey (Smith, 1997a,b; Smith and others, 2007). 
Continuous isochronal reflections can be traced to within $150 \mathrm{~m}$ of the bed over most of the profile. The isochrones between 13 and $22 \mathrm{~km}$ show a signature that has been related to enhanced flow by previous authors, with folds of wavelength around $2 \mathrm{~km}$ which have no correlation with the bed topography (Jacobel and others, 1993; Siegert and others, 2003). Distinctive reflector packages mark the edges of sector B flow; these are described in the Analysis section.

The thickness of the layer of ice between the bed and the deepest continuous isochrone varies across the profile. This variation may be due either to variations in the longitudinal strain or to differential melting of basal ice.

\section{Profile R125 (Fig. 2b)}

This profile is $29 \mathrm{~km}$ long, oriented north-south and has the same acquisition parameters as profile R067. The ice thickness varies between 2000 and $2750 \mathrm{~m}$ above a rough bed. A considerable amount of noise remains around the bed reflection following the migration processing step, which suggests that the bed is also rough in the cross-line direction, i.e. parallel to ice flow. Continuous isochronal reflections can be traced throughout the ice thickness over much of the profile. Tight folding of the deeper isochrones affects most of the profile between 1 and $21 \mathrm{~km}$.

\section{Profile J300 (Fig. 2c)}

This profile is $22 \mathrm{~km}$ long and oriented east-west. These data were acquired in the 2007/08 field season using $20 \mathrm{~m}$ transmit and receive antennae that have a centre frequency of near $3 \mathrm{MHz}$ in the raw data. The final processing also used a $0.8-1.6 \mathrm{MHz}$ passband filter to match as closely as possible the character of profiles R067 and R125. The bed is relatively smooth and the maximum ice thickness is $2540 \mathrm{~m}$ at $4 \mathrm{~km}$ along the profile; the ice thickness reduces to $1950 \mathrm{~m}$ at the eastern end. The isochrones are tightly folded at wavelengths of $1-2 \mathrm{~km}$ throughout this profile and there is no correlation of the folding with the bed topography. The hyperbolic events near the surface between 9 and $16 \mathrm{~km}$ are diffractions from near-surface, buried crevasses.

\section{Profile R200 (Fig. 2d)}

This profile is $17 \mathrm{~km}$ long and oriented west-southwesteast-northeast and was acquired with the same parameters as profile J300. The ice-stream bed has a central peak at $2000 \mathrm{~m}$ depth, and the troughs on either side are $2400 \mathrm{~m}$ deep on the Ellsworth Mountains side of the ice stream and $2200 \mathrm{~m}$ on the eastern side. The wavelengths of the folds in the isochrones are very similar to that on profile J300.

\section{ANALYSIS}

There are distinctive reflector patterns in the profiles that are repeated on each line. Here I describe these patterns and argue that they mark the boundaries of distinct flow elements within the basin. This interpretation allows the calculation of the ice flux for sector B through each of the profiles.

\section{Determination of margin locations}

The margins of sector $\mathrm{B}$ flow were determined from the radar data by recognizing distinctive patterns of reflections that mark the margins, which are common to each profile. On profile R067, the southern margin is marked by a shortwavelength syncline at $3.8 \mathrm{~km}$ (Fig. 2a) which is spatially correlated with a $500 \mathrm{~m}$ step in the bed. Above the syncline there is a complex pattern of reflections with varying dips. There is also a reduction in the amplitude of the isochrones at this point. On the other three profiles, the margin closest to the Ellsworth Mountains is marked by a sharp termination of the isochrones over the full depth, and the termination lies immediately beneath the complex pattern.

The northern or eastern margin of the sector B flow is marked on each profile by two distinctive reflector groups that are closely associated (Fig. 3). On each profile there is a $1 \mathrm{~km}$ wide zone of tightly folded reflections at depths below $1000 \mathrm{~m}$ (marked by polygons in Fig. 3). Above this zone are a group of faint curvilinear reflections (marked by arrows in Fig. 3) that cross-cut the isochrones. These reflections dip towards north or east with dips that increase with depth, forming isolated curves on the profile. Profile R125 is the upstream member of a grid of six lines spaced $5 \mathrm{~km}$ apart (not shown here), and profile R200 is one of a series of 30 lines spaced $500 \mathrm{~m}$ apart. All of the lines show the same curving, cross-cutting reflections, which indicates that the reflecting surfaces are curved in section and linear in the flow direction and that they do not arise from out-of-plane reflection points.

Taken together, these two reflector groups, the zone of tight folds and the curvilinear cross-cutting reflections, constitute a flow-margin signature that marks the boundary between sectors B and C. On profile R067, the pattern of reflectors lies beneath a linear feature in the surface imagery (Fig. 1a) that also corresponds to the edge of enhanced flow measured by InSAR (Fig. 1d). I suggest that the pattern develops in the upstream region where there is flow differential between sectors B and C, and is preserved as the ice advects downstream into the area where little or no flow differential between the sectors remains, i.e. about the location of profile J300.

The inclination of the fold axes in the zone of tight folds (Fig. 3) changes between profiles R125 and J300. On profile R125 the dip is towards the centre of sector B, and on J300 the dip is away from the centre. The flow direction changes through almost $90^{\circ}$ over the same distance. This suggests that some lateral vertical strain takes place as the ice flows around the bend.

The cross-cutting, curvilinear reflections that form part of the flow-margin signature are unusual. Reflections on radar profiles over ice sheets are normally considered to arise from one of three mechanisms: (1) density variations in the firn layer and upper ice (Robin and others, 1969), (2) conductivity variations in compacted ice (Paren and Robin, 1975) or (3) crystal orientation fabrics (COFs) generated in high-strain zones (Fujita and Mae, 1994; Fujita and others, 1999; Eisen and others, 2007). Reflectors caused by these mechanisms are usually surface-parallel, and the reflections are considered isochrones (Bogorodsky and others, 1985; Dowdeswell and Evans, 2004), or, in the case of COF reflections, the fabric develops parallel to the depositional layering due to a strain-enhancement factor resulting from mechanical anisotropy (Fujita and others, 1999). Reflections that cross-cut isochronal reflections must arise from post-depositional effects. In the present case, erosion or non-deposition can be ruled out (cf. Welch and Jacobel, 2005). One possible explanation of the reflections is that they arise from changes 

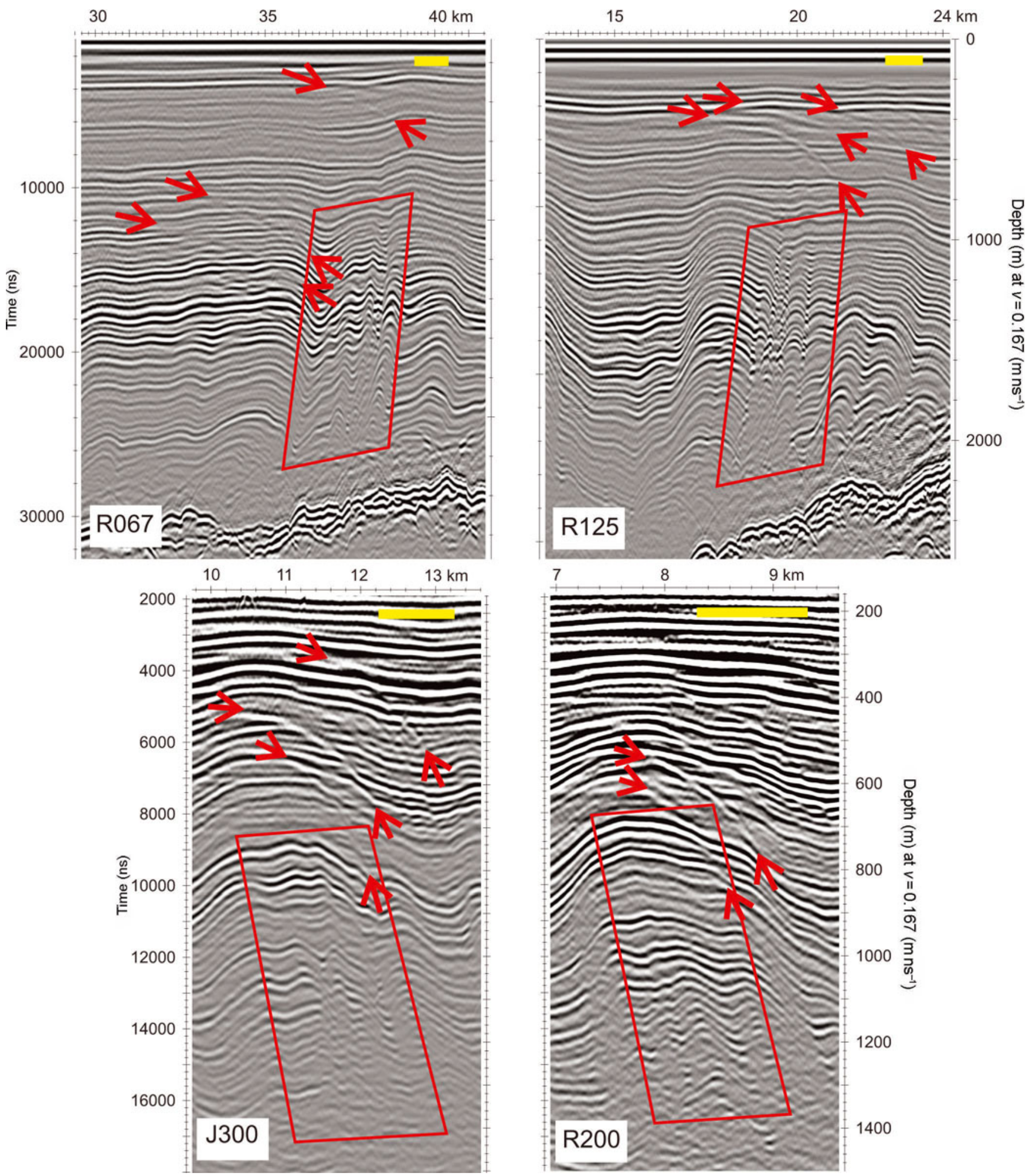

$24 \mathrm{~km}$

Fig. 3. Detailed view of reflector groups marking the boundary between sectors B and C. Arrows mark the ends of faint curvilinear reflections that cross-cut isochronal reflections. Polygons bound a zone of short-wavelength folds. Yellow bar is a $1 \mathrm{~km}$ scale; note that the horizontal scales for profiles J300 and R200 have been stretched to allow comparison of the detail. Ice flow is out of the page.

in COF due to localized strain within the margin of the ice stream in a location where both sides of the margin are moving but at different rates. There is a narrow but deep depression in the basal topography about $30 \mathrm{~km}$ upstream of profile R067 (Fig. 1c): possibly a strain fabric developed due to vertical shear as ice flowed into and out of this depression. Further data are required to determine the origin of these features.
The convergence of flow of sector B ice from the onset area into the main trunk of the ice stream is clearly demonstrated on these profiles. The width of sector B reduces from $35 \mathrm{~km}$ at profile R067 to $8 \mathrm{~km}$ at R200. From considerations of mass continuity, the reduction in crosssectional area from profile to profile should be proportional to the increase in flow speed between profiles $(\mathrm{Ng}$ and Conway, 2004) 


\section{Calculation of flux}

Previous estimates of the flux of ice in the Rutford catchment determined the total flux through the full width of the main trunk of the ice stream, and the average flux determined by these studies was approximately $20 \mathrm{~km}^{3} \mathrm{a}^{-1}$ (Crabtree and Doake, 1982; Joughin and Bamber, 2005). Here I consider the fraction of the total that comes only from sector $B$ in order to begin to refine the ice-flow model for Rutford. At this stage, I use only the most simplistic of flux calculations, which assumes that all of the flow is accommodated by basal sliding or subglacial till deformation, i.e. the vertical velocity gradient is zero. The accurate definition of a flux gate for this flow sector would also need to take into account the inclination of the flow margin at depth. Using the flowmargin information from the radar profiles described previously, the cross-sectional area of sector B ice was measured on each profile. This was done in a series of $1 \mathrm{~km}$ wide sub-gates to correspond with the resolution of the InSAR flow-speed data (Fig. 1d). The flux for each of the subgates was then calculated and the sum taken. The total flux across each profile is shown in Table 1. The flux at the most downstream profile, R200, is estimated as $7.27 \mathrm{~km}^{3} \mathrm{a}^{-1}$, or about $38 \%$ of the total flux through Rutford Ice Stream.

The flux increases in the downstream direction. This result is as expected because of the additional mass due to surface accumulation between the gates. Table 1 shows that the surface accumulation required to maintain balance lies in the range $(0.54 \pm 0.04)-(0.61 \pm 0.05) \mathrm{m} \mathrm{a}^{-1}$ w.e. This accumulation value is not significantly different from the measurement of $0.39 \pm 0.10 \mathrm{~m} \mathrm{a}^{-1}$ w.e. for the period 1780 2001 made at ITASE (International Trans-Antarctic Scientific Expedition) core site 01-5, which lies within sector B (Kaspari and others, 2004). The calculated flux values may be biased towards higher values since they were based on the assumption that the vertical velocity gradient through the ice column is zero because basal sliding or till deformation predominates over internal deformation. This assumption is likely valid in the main trunk of the ice stream, where the flow is fastest. There, the bed is smooth and there are extensive areas of soft sediment beneath the ice (Smith, 1997b, 2006; Smith and others, 2007). However, this assumption may not be valid in the onset region, where the bed is only intermittently smooth and there are extensive areas of rough bed with high topographic relief (see especially profile R125 (Fig. 2b)). In these regions, it is likely that the vertical velocity profile varies across the ice stream as the ratios of internal deformation and basal sliding change with varying basal conditions. To quantify such variation in the vertical velocity profile requires a full forcebalance analysis (Van der Veen and Whillans, 1989) of the catchment along the lines of those performed in the Lambert Glacier region by Fricker and others (2000) or for Heimefrontfjella by Pohjola and others (2004). While such modelling is beyond the scope of this paper, my observations suggest that a force-balance model for the Rutford system should be subdivided into four sectors and each considered as a semi-independent drainage basin.

\section{DISCUSSION}

Of the four sectors of the Rutford ice-drainage basin, sector $B$ supplies the largest volume of ice to the main trunk of the ice stream. Sector B also shares a potentially unstable ice divide with Pine Island Glacier. The ice divide between
Table 1. Ice flux through radar profile gates for sector B

\begin{tabular}{ccccc}
\hline Profile Width & $\begin{array}{c}\text { Max. } \\
\text { thickness }\end{array}$ & Flux & $\begin{array}{c}\text { Area } \\
\text { upstream }\end{array}$ & $\begin{array}{c}\text { Balance } \\
\text { accumulation }\end{array}$ \\
$\mathrm{km}$ & $\mathrm{m}$ & $\mathrm{km}^{3} \mathrm{a}^{-1}$ & $\mathrm{~km}^{2}$ & $\mathrm{ma}^{-1}$ w.e. \\
\hline
\end{tabular}

$\begin{array}{llllll}R 067 & 35 \pm 0.5 & 2760 \pm 20 & 6.43 \pm 0.38 & 10500 \pm 500 & 0.55 \pm 0.05\end{array}$

$\begin{array}{llllll}\mathrm{R} 125 & 19 \pm 0.5 & 2750 \pm 20 & 6.50 \pm 0.31 & 11500 \pm 500 & 0.50 \pm 0.04\end{array}$

$\begin{array}{llllll}\mathrm{J} 300 & 11 \pm 0.5 & 2537 \pm 20 & 7.16 \pm 0.46 & 12300 \pm 500 & 0.52 \pm 0.04\end{array}$

$\begin{array}{llllll}R 200 & 8 \pm 0.5 & 2456 \pm 20 & 7.27 \pm 0.47 & 13400 \pm 500 & 0.49 \pm 0.04\end{array}$

sector B and the southern lobe of Pine Island Glacier is a flow-parallel divide, in contrast to a divide with divergent flow as found where a topographic ridge separates the catchments (as in the case of sector $\mathrm{C}$ and Pine Island Glacier; Fig. 2b). In this circumstance, drawdown of the surface in the Pine Island Glacier catchment due to accelerating ice flow there could cause the lateral migration of the ice divide across-slope towards the east, reducing the area supplying ice to sector B. In the case of sector C, the divide with Pine Island Glacier is a topographic ridge; this will also migrate to the east as surface lowering takes place in Pine Island Glacier, but the rate and manner of divide migration may be different to the sector $\mathrm{B}$ divide because long-term topographic divides may be underlain by a core of relatively stiff ice (Raymond, 1983).

\section{CONCLUSIONS}

Distinctive patterns of reflections in radar profiles can be used to identify internal boundaries within an ice-drainage basin. The patterns advect downstream from their point of origin and undergo distortion during the process of converging flow but remain recognizable. Using this technique, together with satellite-derived information, the icedrainage basin for Rutford Ice Stream was separated into four distinct sections. These observations provide important constraints for future modelling of the Rutford ice-drainage basin. Whether a generalized model of the catchment develops subsections as it evolves or whether the subsections described here have to be defined a priori will provide one form of model sensitivity test. Such modelling is important because approximately one-third of the Rutford catchment boundary adjoins the Pine Island Glacier icedrainage basin and ongoing changes in the Pine Island Glacier flow regime can be expected to affect the catchments adjacent to it.

\section{ACKNOWLEDGEMENTS}

Thanks to C. Griffiths and R. Stilwell for support in the field, together with the operations staff at Rothera Research Station. The InSAR data were supplied by I. Joughin. Helpful reviews were provided by F. $\mathrm{Ng}$ and J. MacGregor.

\section{REFERENCES}

Bogorodsky, V.V., C.R. Bentley and P.E. Gudmandsen. 1985. Radioglaciology. Dordrecht, etc., D. Reidel Publishing Co.

Crabtree, R.D. and C.S.M. Doake. 1982. Pine Island Glacier and its drainage basin: results from radio-echo sounding. Ann. Glaciol., 3, 65-70. 
Doake, C.S.M., R.M. Frolich, D.R. Mantripp, A.M. Smith and D.G. Vaughan. 1987. Glaciological studies on Rutford Ice Stream, Antarctica. J. Geophys. Res., 92(B9), 8951-8960.

Doake, C.S.M. and 7 others. 2001. Rutford Ice Stream, Antarctica. In Alley, R.B. and R.A. Bindschadler, eds. The West Antarctic Ice Sheet: behavior and environment. Washington, DC, American Geophysical Union, 221-235. (Antarctic Research Series 77.)

Dowdeswell, J.A. and S. Evans. 2004. Investigations of the form and flow of ice sheets and glaciers using radio-echo sounding. Rep. Progr. Phys., 67(10), 1821-1861.

Eisen, O., I. Hamann, S. Kipfstuhl, D. Steinhage and F. Wilhelms. 2007. Direct evidence for continuous radar reflector originating from changes in crystal-orientation fabric. Cryosphere, 1(1), 1-10

Fricker, H.A., R.C. Warner and I. Allison. 2000. Mass balance of the Lambert Glacier-Amery Ice Shelf system, East Antarctica: a comparison of computed balance fluxes and measured fluxes. J. Glaciol., 46(155), 561-570.

Frolich, R.M., D.G. Vaughan and C.S.M. Doake. 1989. Flow of Rutford Ice Stream and comparison with Carlson Inlet, Antarctica. Ann. Glaciol., 12, 51-56.

Fujita, S. and S. Mae. 1994. Causes and nature of ice-sheet radioecho internal reflections estimated from the dielectric properties of ice. Ann. Glaciol., 20, 80-86

Fujita, S. and 6 others. 1999. Nature of radio-echo layering in the Antarctic ice sheet detected by a two-frequency experiment. J. Geophys. Res., 104(B6), 13,013-13,024.

Gades, A.M. 1998. Spatial and temporal variations of basal conditions beneath glaciers and ice sheets inferred from radio echo soundings. (PhD thesis, University of Washington.)

Jacobel, R.W., A.M. Gades, D.L. Gottschling, S.M. Hodge and D.L. Wright. 1993. Interpretation of radar-detected internal layer folding in West Antarctic ice streams. J. Glaciol., 39(133), 528-537.

Joughin, I. and J.L. Bamber. 2005. Thickening of the ice stream catchments feeding the Filchner-Ronne Ice Shelf, Antarctica. Geophys. Res. Lett., 32(17), L17503. (10.1029/2005GL023844.)

Joughin, I. and 7 others. 1999. Tributaries of West Antarctic ice streams revealed by RADARSAT interferometry. Science, 286(5438), 283-286.

Joughin, I., E. Rignot, C.E. Rosanova, B.K. Lucchitta and J. Bohlander. 2003. Timing of recent accelerations of Pine Island Glacier, Antarctica. Geophys. Res. Lett., 30(13), 1706. (10.1029/ 2003GL017609.)

Kaspari, S. and 6 others. 2004. Climate variability in West Antarctica derived from annual accumulation-rate records from ITASE firn/ice cores. Ann. Glaciol., 39, 585-594.

King, E.C., J.M. Woodward and A.M. Smith. 2004. Seismic evidence for a water-filled canal in deforming till beneath Rutford Ice Stream, West Antarctica. Geophys. Res. Lett., 31(20), L20401. (10.1029/2004GL020379.)

Liu, H., K.C. Jezek and B. Li. 1999. Development of an Antarctic digital elevation model by integrating cartographic and remotely sensed data: a geographic information system based approach. J. Geophys. Res., 104(B10), 23,199-23,213.

$\mathrm{Ng}$, F. and H. Conway. 2004. Fast-flow signature in the stagnated Kamb Ice Stream, West Antarctica. Geology, 32(6), 481-484.

Paren, J.G. and G.deQ. Robin. 1975. Internal reflections in polar ice sheets. J. Glaciol., 14(71), 251-259.

Pohjola, V.A., J. Hedfors and P. Holmlund. 2004. Investigating the potential to determine the upstream accumulation rate, using mass-flux calculations along a cross-section on a small tributary glacier in Heimefrontfjella, Dronning Maud Land, Antarctica. Ann. Glaciol., 39, 175-180.

Raymond, C.F. 1983. Deformation in the vicinity of ice divides. J. Glaciol., 29(103), 357-373.

Rignot, E.J. 1998. Fast recession of a West Antarctic glacier. Science, 281(5376), 549-551.

Robin, G.deQ., S. Evans and J.T. Bailey. 1969. Interpretation of radio echo sounding in polar ice sheets. Philos. Trans. $R$. Soc. London, Ser. A, 265(1166), 437-505.

Shepherd, A., D.J. Wingham, J.A.D. Mansley and H.F.J. Corr. 2001. Inland thinning of Pine Island Glacier, West Antarctica. Science, 291(5505), 862-864.

Siegert, M.J., A.J. Payne and I. Joughin. 2003. Spatial stability of Ice Stream D and its tributaries, West Antarctica, revealed by radioecho sounding and interferometry. Ann. Glaciol., 37, 377-382.

Smith, A.M. 1997a. Basal conditions on Rutford Ice Stream, West Antarctica, from seismic observations. J. Geophys. Res. 102(B1), 543-552.

Smith, A.M. 1997b. Variations in basal conditions on Rutford Ice Stream, West Antarctica. J. Glaciol., 43(144), 251-261.

Smith, A.M. 2006. Microearthquakes and subglacial conditions. Geophys. Res. Lett., 33(24), L24501. (10.1029/2006GL028207.)

Smith, A.M. and 6 others. 2007. Rapid erosion, drumlin formation and changing hydrology beneath an Antarctic ice stream. Geology, 35(2), 127-130.

Van der Veen, C.J. and I.M. Whillans. 1989. Force budget: I. Theory and numerical methods. J. Glaciol., 35(119), 53-60.

Vaughan, D.G. and 9 others. 2001. A review of Pine Island Glacier basin, West Antarctica: hypotheses of instability vs. observations of change. In Alley, R.B. and R.A. Bindschadler, eds. The West Antarctic Ice Sheet: behavior and environment. Washington, DC, American Geophysical Union, 237-256. (Antarctic Research Series 77.)

Vaughan, D.G., H.F.J. Corr, A.M. Smith, H.D. Pritchard and A. Shepherd. 2008. Flow-switching and water piracy between Rutford Ice Stream and Carlson Inlet, West Antarctica. J. Glaciol., 54(184), 41-48.

Welch, B.C. and R.W. Jacobel. 2003. Analysis of deep-penetrating radar surveys of West Antarctica. Geophys. Res. Lett., 30(8), 1444. (10.1029/2003GL017210.)

Welch, B.C. and R.W. Jacobel. 2005. Bedrock topography and wind erosion sites in East Antarctica: observations from the 2002 USITASE traverse. Ann. Glaciol., 41, 92-96. 